\title{
THE ASSESSMENT OF THE SCOPE OF IMPLEMENTATION OF THE IDEA OF MULTIFUNCTIONAL RURAL DEVELOPMENT IN LAND CONSOLIDATION PROJECTS IN POLAND, ,**
}

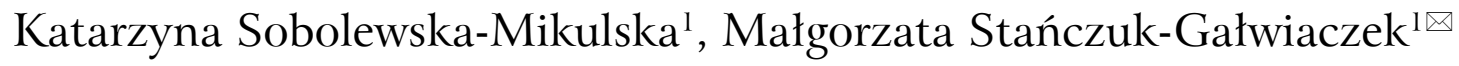 \\ ${ }^{1}$ Warsaw University of Technology, Poland
}

\begin{abstract}
Land consolidation is considered as a tool for accomplishing the goals of multifunctional rural development. However, the mechanisms of execution of the idea do not offer a clear explanation. The aim of this paper is to assess the scope of implementation of the idea of multifunctional rural development in land consolidation projects in Poland. This paper attempts to assess whether all elements of the concept included in land consolidation procedures are dealt with in a sufficient manner. The analyses were based on the example of 15 selected land consolidation projects carried out in disparate regions of Poland. This paper presents the analyses of design solutions concerning three major aspects: the improvement of efficiency of farming, the preservation of the environment and the landscape, the social influence of land consolidation. According to the results of the studies, for all analyzed objects, satisfactory economic results were obtained which indirectly influence the social effects. However, environmental and landscape solutions were only partially considered. The studies have shown, that in Poland it seems necessary to create appropriate organizational and administrative structures in order to generate a tool for implementation of the multifunctional rural development idea within the process of land consolidation.
\end{abstract}

Keywords: land consolidation project, effects of land consolidation, multifunctional rural development, rural areas in Poland

\section{INTRODUCTION}

The model of agriculture existing in the European Union countries indicates the need for the multifunctional development of rural areas. The idea of the multifunctional rural development is moving away from the conventional consideration of the agricultural space as a place of plant and animal production and it is breaking the single-function model of the Polish village. The paradigm emphasizes that in addition to producing food and fibre, agriculture also produces a wide range of non-commodity goods and services, shapes the environment, affects social and cultural systems and contributes to the economic growth (Van Huylenbroeck et al., 2007). Therefore, rural areas - apart from production functions - also offer other functions, such as social (as a place of living

${ }^{*}$ The research was financed from Statutory Research Fund for the work realized at Warsaw University of Technology, Faculty of Geodesy and Cartography, allocated in the for the year 2016 and 2018.

${ }^{* *}$ The results of the study were presented on the Symposium on Land Consolidation and Land Readjustment for Sustainable Development, Apeldoorn, 9-11 November 2016.

$\bowtie$ MSc Eng Małgorzata Stańczuk-Gałwiaczek, Department of Cadastre and Land Management, Warsaw University of Technology, Pl. Politechniki 1, 00-661 Warszawa, Poland, e-mail: Malgorzata.Stanczuk@pw.edu.pl 
Sobolewska-Mikulska, K., Stańczuk-Gałwiaczek, M. (2018). The assessment of the scope of implementation of the idea of multifunctional rural development in land consolidation projects in Poland. J. Agribus. Rural Dev., 1(47), 81-88. http://dx.doi. org/10.17306/J.JARD.2018.00375

for farmers and other inhabitants), ecological, recreational, tourist and economic functions.

A universal definition of the idea of the multifunctional development does not exist. This term has been interpreted in many ways and it refers to different dimensions. Multifunctionality is connected with different functions of particular forms of activity of rural society; it is somehow the result of those activities (Durand and Van Huylenbroeck, 2003). This idea does not refer to the agricultural sector only, its production and economy; it also refers to farmers, their households, and to the quality of their life and work (Woźniak, 2008). Therefore, multifunctional rural development is also connected with the social-and-economic development of rural areas and with their increased attractiveness (Szczurows$\mathrm{ka}$ et al., 2005). The idea is often equalised with diversification, i.e. with creation of other than agricultural types of activities and new places of work. Following Bórawski and Gotkiewicz (2012), the basic assumption of multifunctional development is the improvement of living and working conditions of inhabitants and modernisation and development of the infrastructure in rural areas. This covers the development of all institutions and facilities which are the condition of diversified, social-and-economic development (such as education, housing, transport, communication, social capital etc.) (Krupowicz, 2016). At the same time, it is necessary to keep the balance between agriculture and the environment. Successful development of rural space should enable multidirectional and optimum use of lands, with consideration of environmental and landscape conditions of rural areas.

The idea of multifunctional rural development is not new - it was brought to Europe in the interwar period and after World War II, however, in Poland, due to the economic and political situation at that time, the concept was not properly adopted (Mazurek, 2010). The strengthening of the idea of multifunctional development of rural areas in Poland ensued after the beginning of the political transformation process (Adamowicz i Zwolińska-Ligaj, 2009). According to (Psyk-Piotrowska, 2005; Mazurek, 2010), multifunctional rural development was restored at the end of the 1980s - the idea was addressed in numerous scientific articles (DuczkowskaMałysz, 1993; Kaleta, 1998; Kłodziński, 1997), and then included in strategic government documents. The accession of Poland to the European Union in 2004 introduced favorable conditions for the implementation of the idea (due to developed instrumentation enabling the realization of agri-environment and climate-related measures supporting the development of rural areas, included in Rural Development Programmes (RDP) within the framework of Common Agricultural Policy) (Adamowicz i Zwolińska-Ligaj, 2009). The basic objective of RDP for the periods 2014-2020 is to improve the competitiveness of agriculture, sustainable management of natural resources and actions performed in the field of climate, as well as the sustainable territorial development of rural areas" (MARD, 2014).

The multifunctional development of rural areas will be implemented, among others, by means of land consolidation works, which were included in the RDP 2014-2020 as the activity 4.3 "Support for investments in the infrastructure connected with the development, modernisation and adaptation of the agricultural and forestry sector (Land consolidation)". As it turns out, from research works performed by Bielska (2012) the multifunctional, sustainable development of rural areas, where land layout is inconvenient and disadvantageous, is hampered without land consolidation works.

The basic definition and the objective of land consolidation works are included in the act of 26 March 1982 on land consolidation and exchange (the unified text Dz. U. of 2014 r., item 700 with amendments). Land consolidation was defined as agricultural operations aiming at transformation of lands located in rural areas in order to create more advantageous conditions for agriculture and forestry by means of improvements in the area structure of farms, rational arrangements of shape expanse of fields and the adjustment of real property borders to the system of water meliorations, roads and the terrain relief.

Thus, the Polish legislation defines the basic objective of land consolidation as the achievement of spatial results connected with changes in the size of the ownership and the land use in farms, as well as the rational arrangements of the agricultural transport roads, corrections in water melioration system and other elements of the technical infrastructure. Other issues, such as management of the natural environment, are not discussed by the act.

In accordance with the Common Agricultural Policy, the approach to land consolidation should be more complex and, besides the agriculture, also other values of the country side should be considered in the process. The paradigm changed converting land consolidation 
Sobolewska-Mikulska, K., Stańczuk-Gałwiaczek, M. (2018). The assessment of the scope of implementation of the idea of multifunctional rural development in land consolidation projects in Poland. J. Agribus. Rural Dev., 1(47), 81-88. http://dx.doi. org/10.17306/J.JARD.2018.00375

from 'agricultural restructuring' to 'comprehensive land reallocation' that might be called 'multifunctional land consolidation' (Van Dijk, 2003). The extended scope of land consolidation results from the concept of the multifunctional development of rural areas. The land consolidation process should be understood as operations which modernise rural areas, resulting in:

- new arrangements in land use,

- correct development of network of agricultural transport roads and improvement in exterior and interior transportation,

- protection of the natural environment and landscape development,

- protection of soils,

- exclusion of marginal lands from agricultural use,

- rationalisation of water management,

- increase of recreation values, development of agrotourism and rural tourism,

- revalorisation of rural areas,

- development of rural areas,

- protection of the cultural heritage of rural areas,

- creation of new places of jobs (Akińcza and Malina, 2007).

\section{MATERIALS AND METHODS}

The aim of this paper is to assess the scope of implementation of the idea of multifunctional rural development in land consolidation projects in Poland. The paper attempts to assess whether all elements of the concept included in land consolidation procedures in Poland are dealt with in a sufficient manner. The studies were based on the example of 15 randomly selected land consolidation projects carried out in disparate regions of Poland and different time periods (Fig. 1). The scope of design solutions included in the "Assumptions for the land consolidation project" for each test site was analyzed. The implementation of the design solutions was verified.

Analyzed applications were grouped according to 3 groups of effects of land consolidation works, performed within multifunctional and sustainable development:

- economic and technical effects (the improvement of farming efficiency in agricultural holdings),

- environmental effects (the protection and preservation of environment and landscape shaping, inter alia water and soil protection, the realization of agriculture-forest boundaries, introduction of trees, shrubs and buffer zones), and

- social effects of land consolidation.

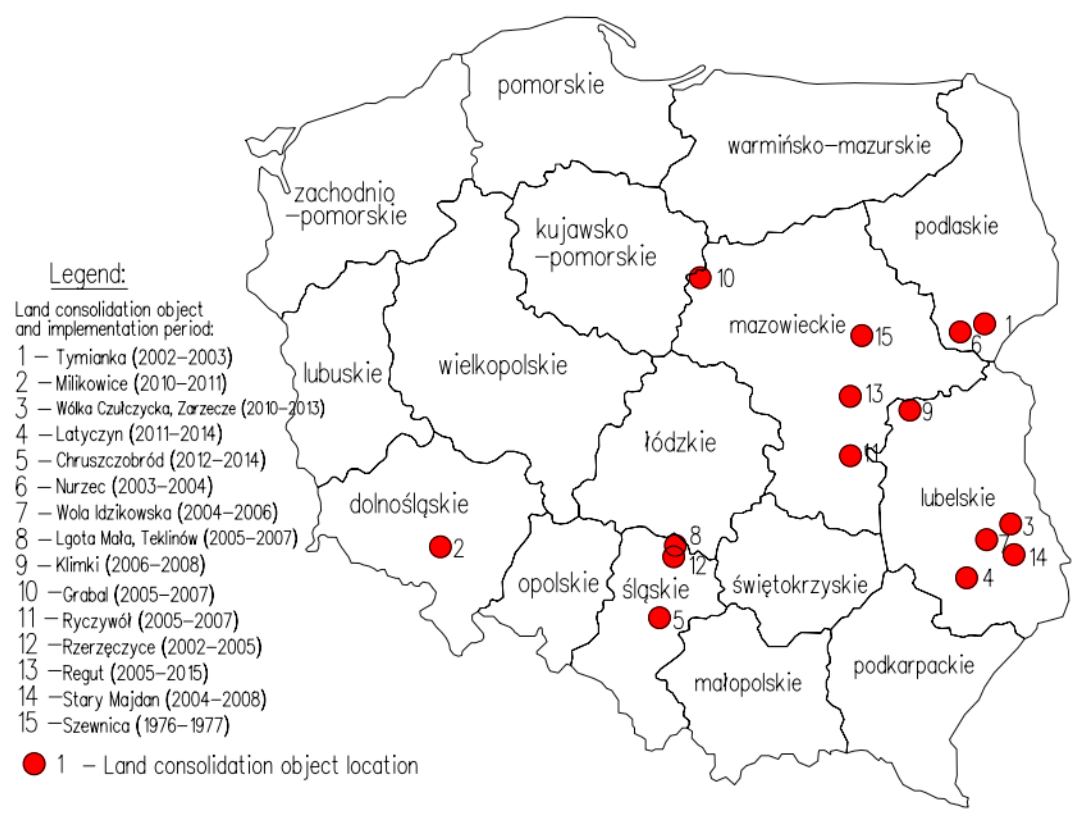

Fig. 1. Indicative location of test sites in Poland Source: own elaboration 
Sobolewska-Mikulska, K., Stańczuk-Gałwiaczek, M. (2018). The assessment of the scope of implementation of the idea of multifunctional rural development in land consolidation projects in Poland. J. Agribus. Rural Dev., 1(47), 81-88. http://dx.doi. org/10.17306/J.JARD.2018.00375

\section{RESULTS}

According to the results of the studies, for all analyzed objects, satisfactory economic results were obtained. Land consolidation has, among others, contributed to the improvement of the field shape expanse of agricultural holdings and elimination of the patchwork of arable and forest parcels. In all analyzed cases, significant improvement of the basic parameters which characterise the spatial structure of lands (the coefficient of decrease in the total number of parcels and the coefficient of increase in the size of the average plot for examined objects) was noted. For all objects, land consolidation works were considered as the final operation aiming at the improvement of conditions in the sphere of the spatial structure of farms and forest households. For 13 out of 15 analyzed objects, land consolidation resulted in development of a functional network of agricultural roads and ensured access to a public road for every plot.
Activities related to restoration and reconstruction of the water melioration system and improvement of technical conditions of the melioration ditches system were not commonly implemented (for 7 out of 15 analyzed cases). Synthetic description of the obtained research results concerning the scope of implementation of land consolidation design solutions affecting economic and technical aspects is presented in tabular form (Table 1).

Attention is drawn to the ambiguity of the concept of landscape - it functions in a number of fields of science, and its most appropriate interpretation is widely discussed among the representatives of particular scientific disciplines (Kulczyk, 2009; Myga-Piątek, 2001, 2012). This paper does not introduce the taxonomic classification of the concept, because according to specialists in the field of landscape science (Mania, 2007; Pietrzak, 2006), the division into the natural and cultural landscape is artificial, due to the fact that the landscape itself contains elements of the natural environment and

Table 1. The scope of implementation of land consolidation design solutions affecting economic and technical aspects

\begin{tabular}{|c|c|c|c|c|c|c|c|c|c|c|c|c|c|c|c|}
\hline \multirow{2}{*}{ Design solution } & \multicolumn{15}{|c|}{ Land consolidation object } \\
\hline & 1 & 2 & 3 & 4 & 5 & 6 & 7 & 8 & 9 & 10 & 11 & 12 & 13 & 14 & 15 \\
\hline $\begin{array}{l}\text { Reduction of the number of parcels } \\
\text { (increased area of an average plot) }\end{array}$ & + & + & + & + & + & + & + & + & + & + & + & + & + & + & + \\
\hline $\begin{array}{l}\text { Improvement of the field expanse } \\
\text { and shape of parcels }\end{array}$ & + & + & + & + & + & + & + & + & + & + & + & + & + & + & + \\
\hline $\begin{array}{l}\text { Elimination of the patchwork } \\
\text { of arable and forest parcels }\end{array}$ & + & + & + & + & + & + & + & + & + & + & + & + & + & + & + \\
\hline Elimination of land communities & + & + & + & + & + & + & + & + & + & + & + & + & + & + & + \\
\hline $\begin{array}{l}\text { Creating opportunities to increase } \\
\text { the size of farms }\end{array}$ & + & + & + & + & + & + & + & + & + & + & + & + & + & + & + \\
\hline $\begin{array}{l}\text { Ensuring the access to a public road } \\
\text { for every plot }\end{array}$ & - & + & + & + & + & + & + & + & + & - & + & + & + & + & + \\
\hline $\begin{array}{l}\text { Development of a functional network } \\
\text { of agricultural roads }\end{array}$ & - & + & + & + & + & + & + & + & + & - & + & + & + & $+1-$ & + \\
\hline $\begin{array}{l}\text { Improvement of technical conditions } \\
\text { of the melioration ditches system }\end{array}$ & + & + & + & + & + & - & - & + & - & + & - & - & - & - & - \\
\hline $\begin{array}{l}\text { Restoration or reconstruction } \\
\text { of the water melioration system }\end{array}$ & + & + & + & - & + & - & - & + & - & + & + & - & $+1-$ & - & - \\
\hline
\end{tabular}

+ implemented operation

- unimplemented operation

+/- operation not completed at the sufficient level

Source: own elaboration. 
Sobolewska-Mikulska, K., Stańczuk-Gałwiaczek, M. (2018). The assessment of the scope of implementation of the idea of multifunctional rural development in land consolidation projects in Poland. J. Agribus. Rural Dev., 1(47), 81-88. http://dx.doi. org/10.17306/J.JARD.2018.00375

products of civilization. For the needs of the paper, landscape means an area, as perceived by people, whose character is the result of the action and interaction of natural and/or human factors (it consists of all natural and anthropogenic features distinguishing a specific area) (Baranowska-Janota i in., 2004; European Landscape Convention, 2000; Mania, 2007; Szulczewska, 2009).

In all analyzed cases, land consolidation project did not have a significant impact on landscape shaping or environmental protection on the test site. Environmental and landscape solutions were only partially considered and land consolidation did not serve as a tool that would significantly strengthen the protection of biodiversity and landscape features of great natural value. For $10 \mathrm{ob}-$ jects there were implemented operations aimed at the increasing woodiness and regulations of borders between forests and arable fields. Remaining landscape creating operations (such as introduction of trees and bushes, buffer zones, construction of small retention reservoirs) were seldom performed (Table 2). However, environmental-and-landscape conditions were not deteriorated as a result of any land consolidation processes. It is not possible to state whether this resulted from attempts to maintain the existing state of landscape characteristics (including valuable nature components of landscape) or from the general reluctance to undertake any

Table 2. The scope of implementation of land consolidation design solutions affecting environmental aspects

\begin{tabular}{|c|c|c|c|c|c|c|c|c|c|c|c|c|c|c|c|}
\hline \multirow{2}{*}{ Design solution } & \multicolumn{15}{|c|}{ Land consolidation object } \\
\hline & 1 & 2 & 3 & 4 & 5 & 6 & 7 & 8 & 9 & 10 & 11 & 12 & 13 & 14 & 15 \\
\hline $\begin{array}{l}\text { Maintaining the high natural value } \\
\text { areas in natural conditions }\end{array}$ & + & + & + & + & + & + & + & + & + & + & + & + & + & + & + \\
\hline $\begin{array}{l}\text { Maintaining and protection } \\
\text { of existing, inter-field trees }\end{array}$ & + & + & + & + & + & + & + & + & $+/-$ & + & + & + & + & + & + \\
\hline $\begin{array}{l}\text { Introduction of trees and bushes along } \\
\text { transportation routes }\end{array}$ & $+/-$ & $+1-$ & - & - & - & - & $+1-$ & - & - & - & - & - & - & - & - \\
\hline $\begin{array}{l}\text { Introduction of rows or belts } \\
\text { of woodlots on balks }\end{array}$ & $+1-$ & - & - & - & - & - & - & - & - & - & - & - & - & - & + \\
\hline $\begin{array}{l}\text { Forestation and regulations of borders } \\
\text { between fields and forests }\end{array}$ & - & - & + & - & + & + & - & + & - & + & $+1-$ & + & + & + & + \\
\hline Protection of soils, anti-erosion works & - & - & - & - & - & - & $+/-$ & - & - & - & - & - & - & + & - \\
\hline $\begin{array}{l}\text { Maintaining or introduction } \\
\text { of "ecological" roads }\end{array}$ & $+1-$ & - & - & - & - & - & - & - & - & - & - & - & - & + & - \\
\hline $\begin{array}{l}\text { Re-cultivation of fallows, } \\
\text { management of wastelands }\end{array}$ & - & - & - & - & - & + & $+1-$ & $+1-$ & - & - & - & $+1-$ & $+1-$ & - & $+1-$ \\
\hline $\begin{array}{l}\text { Introduction of buffer zones along } \\
\text { streams }\end{array}$ & + & - & - & - & - & - & - & - & - & - & - & - & - & - & - \\
\hline $\begin{array}{l}\text { Regulation of water conditions } \\
\text { on periodically flooded or dry lands }\end{array}$ & - & + & - & - & + & - & - & + & - & + & + & - & $+/-$ & - & - \\
\hline $\begin{array}{l}\text { Construction of small water retention } \\
\text { reservoirs }\end{array}$ & - & + & - & - & - & - & - & - & - & + & - & - & - & - & + \\
\hline Flood protection & - & - & - & - & - & - & - & - & - & - & - & - & - & - & - \\
\hline
\end{tabular}

+ implemented operation

- unimplemented operation

+/- operation not completed at the sufficient level

Source: own elaboration. 
Sobolewska-Mikulska, K., Stańczuk-Gałwiaczek, M. (2018). The assessment of the scope of implementation of the idea of multifunctional rural development in land consolidation projects in Poland. J. Agribus. Rural Dev., 1(47), 81-88. http://dx.doi. org/10.17306/J.JARD.2018.00375

operations in this field. Besides, some test sites, such as Nurzec, were characterised by its high environmental-and-landscape values and the occurrence of ecosystems of high natural value, requiring protection (e.g. forest ecosystems, mid-field groups of trees and shrubs, mid-field ponds, wetlands and meadows of high biodiversity). Such test sites did not require any landscape creating operations; in this case only activities aimed at preservation and protection of existing environmental and landscape values were required.

For all analysed objects, satisfactory economic results were obtained. They were connected with improvements in expanse of fields and with the rational development of the functional network of the agricultural transport roads. Obtained economic results indirectly influence the social effects. It can be assumed that

Table 3. The scope of implementation of land consolidation design solutions affecting social aspects

\begin{tabular}{|c|c|c|c|c|c|c|c|c|c|c|c|c|c|c|c|}
\hline \multirow{2}{*}{ Design solution } & \multicolumn{15}{|c|}{ Land consolidation object } \\
\hline & 1 & 2 & 3 & 4 & 5 & 6 & 7 & 8 & 9 & 10 & 11 & 12 & 13 & 14 & 15 \\
\hline $\begin{array}{l}\text { Actions directed on development of tourism and } \\
\text { different forms of active and passive recreation }\end{array}$ & $-{ }^{\mathrm{A})}$ & $+^{\mathrm{B})}$ & - & - & - & $-{ }^{\text {A) }}$ & - & - & - & - & - & - & - & - & - \\
\hline Planning sites for organisation of open-air events & - & - & - & - & + & - & - & - & - & - & - & - & - & - & - \\
\hline \multicolumn{16}{|l|}{$\begin{array}{l}\text { Destination of lands for investment and public } \\
\text { services: }\end{array}$} \\
\hline $\begin{array}{l}\text { - increase of size of urban areas/destination } \\
\text { of lands for development of existing urban areas }\end{array}$ & - & + & $+^{\mathrm{D})}$ & + & - & - & - & $+^{\mathrm{G})}$ & - & - & - & - & - & - & - \\
\hline $\begin{array}{l}\text { - planning special areas for the needs } \\
\text { of the social and technical infrastructure }\end{array}$ & - & - & - & $+^{\mathrm{E})}$ & $+^{\mathrm{F})}$ & - & - & $+^{\mathrm{H})}$ & - & - & $+^{\mathrm{I})}$ & - & - & - & $+^{\mathrm{L})}$ \\
\hline $\begin{array}{l}\text { - increasing the areas for food production } \\
\text { and processing, for services and craftsmen }\end{array}$ & - & - & - & - & - & - & - & - & - & - & $+^{\mathrm{J})}$ & - & $+^{\mathrm{K})}$ & - & - \\
\hline \multicolumn{16}{|l|}{ Renovation of villages through: } \\
\hline $\begin{array}{l}\text { - re-enactment of traditions and increasing } \\
\text { the attractiveness of the landscape }\end{array}$ & - & $+^{\mathrm{C})}$ & - & - & - & - & - & - & - & - & - & - & - & - & - \\
\hline - renovation of abandoned and empty buildings & - & - & - & - & - & - & - & - & - & - & - & - & + & - & $+^{\mathrm{M})}$ \\
\hline Creation of new places of job & - & - & - & - & - & - & - & - & - & - & - & - & - & - & - \\
\hline
\end{tabular}

+ implemented operation.

- unimplemented operation.

A) Despite the potential, there was nothing done that could contribute to the development of tourism and various forms of active and passive recreation.

B) Walking trails, bike paths and viewpoints were planned.

C) Creation of avenues of fruit trees increased the attractiveness of the landscape.

D) Land bank for the development of houses was designated according to the local development plan.

E) Land for the construction of school and sports field was designated.

F) Area for parking at the cemetery and parking at the health center was designated.

G) Large plots along the county road were designated for future investments of service and industrial developments.

H) Land for the construction of full-size sports field, sports and recreation playground and land

for the sewage pumping station were designated.

I) Area for parking at the parish cemetery was designated.

J) Approximately 23 hectares of land for manufacturing and processing activities were allocated.

K) Industrial areas and areas for service and crafts service development were designated (in total approximately 4 ha).

L) Area for enlargement of school plot was designated.

M) Outbuildings of distillery and infrastructure of railway station were arranged.

Source: own elaboration. 

tifunctional rural development in land consolidation projects in Poland. J. Agribus. Rural Dev., 1(47), 81-88. http://dx.doi. org/10.17306/J.JARD.2018.00375

the increased economic effectiveness of farms results in improvement of the quality of life of inhabitants, their activity and acceleration of the further development of rural areas. Social effects connected with mental and emotional changes and activity of the rural society, resulting from the land consolidation process, may be considered in this context.

However, when it comes to design solutions directly affecting social effects, they were rarely introduced (on single land consolidation objects) and were mainly limited to actions directed on development of tourism and different forms of active and passive recreation and destination of lands for investment and public services. Synthetic description of the obtained research results concerning the scope of implementation of land consolidation design solutions affecting social aspects is presented in tabular form (Table 3).

\section{SUMMARY AND CONCLUSIONS}

Results of the research based on 15 test sites suggest that - according to the binding definition of land consolidation - land consolidation works were correctly performed for all objects. But did those works encourage to perform changes in the entire village? In any analyzed case, land consolidation has not become a part of a wider process such as, for example, the increased multi-functionality of a given area. All object land consolidation works were considered as the final operation aiming at the improvement of conditions in the sphere of the spatial structure of farms and forest households.

All analyzed land consolidation works created the possibility to make changes in the area of ineffective farms and set the legal status of real properties, eliminated co-ownership and reduced the patchwork of fields. On the basis of the study results, the following intuitive findings are also emerging: land consolidation process might present the opportunity to implement social initiatives which lead to improved functioning of civil society. Additionally, the activity and initiatives of inhabitants, presented during the land consolidation works, help to undertake further, common actions even when the land consolidation process is completed.

In Poland there is no legal basis concerning the idea of multifunctional development of rural areas. This term appears in Rural Development Programmes, but - to the contrary of many European Union countries (such as Germany, the Netherlands) - its legally binding definition does not exist in Poland. Besides, there are no directions and guidelines which would suggest how the idea of multifunctional development of rural areas could be implemented in practice. For the appropriate implementation of this idea in Poland, it seems necessary to enact the legal act on development of rural areas which would institutionalise the land consolidation process in the complex approach, considering land consolidation together with environmental protection, landscape management, water management and restoration of villages. This would allow for creation of appropriate organisational-and-administrative structures and coherent sources of funds, and, therefore, the generation of a tool for implementation of the multifunctional development of rural areas. The current organisational status (many decision-making organisational units, not mutually connected), as well as financial aspects (many sources of funds for particular activities) are limiting the possibilities to implement operations connected with the multifunctional development of rural areas in the land consolidation process.

\section{REFERENCES}

Act of 26 March 1982 on land consolidation and exchange (2014). Dz. U. item 700 with amendments.

Adamowicz, M., Zwolińska-Ligaj, M. (2009). Koncepcja wielofunkcyjności jako element zrównoważonego rozwoju obszarów wiejskich [The Concept of Multifunctionality as an Element of Sustainable Development of Rural Areas]. Zesz. Nauk. SGGW Warsz.. Pol. Eur. Fin. Market., 2(51), 11-38.

Akińcza, M., Malina, R. (2007). Geodezyjne urządzanie terenów rolnych. Wykłady i ćwiczenia [Geodetic arrangement of rural areas. Lectures and exercises] (p. 57-62). Wrocław: Wyd. Uniwersytetu Przyrodniczego we Wrocławiu.

Baranowska-Janota, M., Marcinek, R., Myczkowski, Z. (2004). Czerwona księga krajobrazu Polski. Projekt pilotażowy tematu (Opracowanie na zlecenie Ministerstwa Środowiska) [The Red Book of Landscapes of Poland. Pilot project (study commissioned by the Ministry of the Environment)]. Kraków. Retrieved 11th Dec 2017 from: https://archiwum.mos.gov.pl/g2/big/2015_11/100ffeb90e 324436b27e45b5e9080237.pdf

Bielska, A. (2012). Wpływ procesu scalenia gruntów na wielofunkcyjny, zrównoważony rozwój obszarów wiejskich [The influence of the land consolidation process on multifunctional sustainable development of rural areas]. Infr. Ecol. Rural Areas, 1(II), 5-14. 
Sobolewska-Mikulska, K., Stańczuk-Gałwiaczek, M. (2018). The assessment of the scope of implementation of the idea of multifunctional rural development in land consolidation projects in Poland. J. Agribus. Rural Dev., 1(47), 81-88. http://dx.doi. org/10.17306/J.JARD.2018.00375

Bórawski, P., Gotkiewicz, W. (2012). Factors contributing to the multifunctional development of rural areas in the opinion of farmers with alternative sources on income. In: P. Bórawski (Ed.), Multifunctional development of rural areas. International experience (p. 11-22). Ostrołęka: Wyd. Wyższej Szkoły Ekonomiczno-Społecznej w Ostrołęce.

Duczkowska-Małysz, K. (1993). Przedsiębiorczość na obszarach wiejskich: w stronę wsi wielofunkcyjnej [Entrepreneurship in rural areas: towards a multifunctional village]. Warszawa: PAN, FRNP.

Durand, G., Van Huylenbroeck, G. (2003). Multifunctionality and rural development; a general framework. In: G. Van Huylenbroeck, G. Durand (Eds.), Multifunctional Agriculture: A New Paradigm for European Agriculture and Rural Development (p. 1-16). Aldershot: Ashgate.

European Landscape Convention (2000). Council of Europe, European Treaty Series - No. 176, Doc. 8833, Florence, 20 October 2000. Dz. U. (2006) No. 14 item 98.

Kaleta, A. (1998). Obszar wiejski i koncepcje jego rozwoju [Rural area and concepts of its development]. In: A. Kaleta (Ed.), Rozwój obszarów wiejskich w perspektywie integracji z Unią Europejską [Rural development in the perspective of integration with the European Union] (p. 45-61). Toruń: UMK.

Kłodziński, M. (1997). Wielofunkcyjny rozwój terenów wiejskich w Polsce i krajach Unii Europejskiej [Multifunctional development of rural areas in Poland and European Union countries]. Warszawa: SGGW.

Krupowicz, W. (2016). Metodyka kształtowania sieci dróg $\mathrm{w}$ pracach scaleniowych na obszarach wiejskich z uwzględnieniem aspektów środowiskowo-krajobrazowych [Methodology of development of the road network in consolidation works in rural areas with consideration of environmental-landscape aspects] (p. 31-41). Dissertation. Warszawa: Politechnika Warszawska.

Kulczyk, S. (2009). Ekologia-krajobraz-turystyka: w poszukiwaniu wspólnego mianownika. Problemy ekologii krajobrazu [Ecology - landscape - tourism: in search of a common denominator], XXIII, 47-51.

Mania, W. (2007). Krajobraz - o czym właściwie mówimy? [Landscape: what exactly are we talking about?]. Genius Loci (bezpłatny dodatek do miesięcznika Urbanista), 6, 1, 7 .

MARD (2014). The Ministry of Agriculture and Rural Development. Retrieved Oct 11th 2016 from: http://www. minrol.gov.pl/Wsparcie-rolnictwa/Program-Rozwoju-Obszarow-Wiejskich-2014-2020

Mazurek, J. (2010). Rozwój obszarów wiejskich w Polsce przegląd koncepcji teoretycznych [Development of Rural Areas in Poland - Review of Theoretical Concept]. Zesz. Nauk. Wydz. Nauk Ekon. Polit. Koszal., 14, 61-81.
Myga-Piątek, U. (2001). Spór o pojęcie krajobrazu w geografii i dziedzinach pokrewnych [A dispute about the koncept of landscape in geography and related fields]. Przegl. Geogr., 73(1-2), 163-176.

Myga-Piątek, U. (2012). Krajobrazy kulturowe. Aspekty ewolucyjne i typologiczne [Cultural landscape. Evolutionary and typological aspects]. Katowice: Uniwersytet Śląski.

Pietrzak, M. (2006). Krajobraz - między naturą a kulturą (czy istnieją krajobrazy kulturowe?) [Landscape - between nature and culture (are there cultural landscapes?)]. In: W. Wołoszyn (Ed.), Krajobraz kulturowy - cechy, walory, ochrona [Cultural landscape - features, values, protection]. Probl. Ekol. Krajob., XVIII, 115-118.

Psyk-Piotrowska, E. (2005). Demarginalizacja wsi drogą: urbanizacji, skansenizacji, samodzielnego rozwoju [Demarginalization of the countryside leading to: urbanization, open-air museum, independent development]. Paper presented at the conference: Przyszłość wsi polskiej a rola państwa polskiego, polityki rolnej UE oraz aktywności mieszkańców [The future of the Polish village and the role of the Polish state, the EU agricultural policy and the activity of the inhabitants]. Retrieved Nov 23rd 2017 from: http:// www.isp.org.pl/files/5817730480358727001128607475. pdf

Szczurowska, M., Podawca, K., Gworek, B. (2005). Wielofunkcyjny rozwój terenów wiejskich szansą dla wsi [Multipurpose development of rural areas chance to village]. Ochr. Środ. Zas. Natur., 28, 49-59.

Szulczewska, B. (2009). Przyroda, środowisko, krajobraz w planowaniu przestrzennym [Nature, environment, and landscape in spatial planning]. In: B. Domański, W. Kurek (Eds.), Gospodarka i Przestrzeń. Prace dedykowane Profesor Danucie Ptaszyckiej-Jackowskiej [Economy and Space] (p. 305-319). Kraków: IGiGP UJ.

Woźniak, M. (2008). Dywersyfikacja szansą rozwoju indywidualnych gospodarstw rolnych $\mathrm{w}$ globalnej gospodarce [Diversification as an opportunity for development of individual agricultural farms in global economy]. Ekon. Org. Gosp. Żywn., 67, 15-24.

Van Dijk, T. (2003). Dealing with Central European land fragmentation. A critical assessment on the use of Western European instruments (p. 137-138). Delft: Uitgeverij Eburon.

Van Huylenbroeck, G., Vandermeulen, V., Mettepenningen, E., Verspecht, A. (2007). Multifunctionality of Agriculture: A Review of Definitions, Evidence and Instruments. Liv. Rev. Lands. Res., 1(3), 5-43. 